\title{
Presentation by François Alabrune
}

\author{
Director of Legal Affairs of the Ministry of Europe and Foreign Affairs, \\ France
}

The International Law Commission is particularly important for France, given its essential mission to codify and develop international law. Respect for international law is a guiding principle of France's foreign policy and also a decisive element of our national legal system. Indeed, it was in France that "constitutional monism" was first posited, in the 1946 Constitution, at the initiative of the first French member of the Commission, Professor Georges Scelle. This explains why, since the creation of the International Law Commission, France has been determined to contribute actively to the Commission's work.

The relationship between the International Law Commission and States is undoubtedly crucial to the success of the Commission's work. In the lifetime of the Commission, this success has been due to the positive dynamic that has consistently characterized this relationship for a long time. However, in recent years some questions have been raised, including on the advisability of maintaining the Commission in existence, at least in its current form.

I shall therefore first consider the main features of the relationship between the Commission and the Member States of the United Nations, which is largely the basis for the proper functioning of the Commission and the success of its work. Second, I shall discuss the structural challenges facing the Commission, as suggested by the title of this panel. Third, I shall attempt to suggest possible ways of dealing with these challenges.

\section{Achievements of the Relationship between the International Law Commission and the Member States of the United Nations}

The first comment to be made is that the International Law Commission has close ties to the Member States of the United Nations. The Commission resulted from the desire of States, expressed in General Assembly resolution 174 (II), to establish it as a subsidiary organ of the Assembly. ${ }^{1}$ The goal was for States to have an expert body able to promote the codification and progressive development of international law.

$1 \quad$ UNGA Res 174(II) (21 November 1947), annex. 
Moreover, the Commission is composed of members elected by the General Assembly from a list of candidates submitted by the governments of Member States. Some members of the Commission previously represented their governments in the Sixth Committee. Others have simultaneously performed or continue to perform official functions.

Lastly, States have an opportunity to express their positions and views at many stages of the Commission's work: (i) through the General Assembly and its Sixth Committee, they may propose topics for inclusion on the agenda - something they undoubtedly still do too seldom; (ii) they state their views on the topics included in the programme of work and decide the order of priority; (iii) they submit information and observations on the items on which the Commission is working and comment on the drafts that it prepares; (iv) each year they receive the Commission's report, which is then submitted for the consideration of the Sixth Committee, offering States an opportunity to conduct an ongoing dialogue with the Commission; (v) they have the last word on the ultimate fate of the work done; and (vi) when the work involves drafting of a convention, they participate in the relevant negotiations and are expected to sign and ratify the convention.

A second comment concerns the importance of the relationship between States and the Commission for the Commission's proper functioning: meeting the expectations of States is essential to the success of the Commission's work, whether this involves the codification or the progressive development of international law.

Meeting the expectations of States is inherent to the Commission's codification mission. This requires it to examine in detail practices and viewpoints of States. As indicated in article 15 of its statute, the task of the Commission is "the more precise formulation and systematization of rules of international law in fields where there already has been extensive State practice, precedent and doctrine".

The task of codification involves collecting information on the topic under study, with a view to extracting from it a synthesis reflecting, as harmoniously as possible, the practice of States in that regard. This task is complicated by the diversity of cultures and legal systems in the world. It falls mainly to the Special Rapporteurs.

Meeting the expectations of States is also crucial for the other mission of the Commission: the progressive development of international law. According to article 15 of the Statute, this concerns "subjects which have not yet been regulated by international law or in regard to which the law has not yet been sufficiently developed in the practice of States". ${ }^{3}$

2 Ibid.

3 Ibid. 
As part of this process, the comments and observations provided by governments and the wishes that they express, as well as the dialogue with members of the Sixth Committee, are extremely important, although ultimately it is the General Assembly that decides the fate of the work done: whether to take no action, to take note of the report or to use it as a basis for the adoption of a convention.

The quality of the relationship between the Commission and States is thus crucial to the success of the Commission's work. It has in the past enabled the Commission to contribute to the adoption of major international conventions, thus meeting the very expectation underlying its establishment: progressive development and codification of international law. The more limited results obtained by the Commission recently can be explained partly by the challenges encountered in the relationship between the Commission and the Member States of the United Nations.

II

Challenges in the Relationship between the International Law Commission and the Member States of the United Nations

Now that we are "drawing a balance for the future" of the International Law Commission, several factors can be cited to explain the questions being asked about the Commission.

A first factor is the limited means available to States to follow and participate effectively in the work of the Commission. One or more representatives must be mobilized in order to follow the Sixth Committee discussions on the Commission's report. However, it is not enough to attend the Sixth Committee's debate during the International Law Week. Preparation is also necessary and this requires significant work. It is also difficult for States to transmit to the Commission their observations on all the topics on which the Commission requests information each year under Chapter III of its report. The multiplicity of topics dealt with by the Commission makes it difficult for States and for the Commission itself to deal with them in depth.

The second factor is probably the limited means available to the Commission itself to cover the diversity of State practice, culture and opinions. The biggest risk for the Commission is that it will be inspired by a single vision, a single legal culture or even a single language. This is why an effort must be made to enable Special Rapporteurs to receive useful information on the evolution of the various legal systems.

The third factor, in view of the limited means available to States, concerns the topics dealt with by the Commission. There are undoubtedly too many 
topics in the Commission's programme of work: nine this year and 11 last year. The multiplicity of projects does not facilitate in-depth study of them and slows down the work. As well as their number, the content of topics may be debatable.

Moreover, the success of the Commission's work depends on topics being selected which are of specific interest to States, which do not give rise to strong objections among them and on which they are prepared to adopt a convention in a specific area. Since its establishment in 1947, the International Law Commission has done a considerable amount of work on classical branches and subjects of international law: diplomatic and consular law, law of treaties, succession, law of the sea, responsibility of States and international organizations, etc. However, in recent years, certain topics included in the Commission's programme of work seem more questionable. Work on protection of the atmosphere, for example, requires technical expertise and is probably of limited legal interest.

The fourth factor is undoubtedly the temptation for the Commission to stop proposing draft conventions and to favour the formulation of soft law rules. If the Commission and the Special Rapporteurs want their work to be the basis for adoption of an international convention, they must achieve a sufficiently consensual outcome. Substantive dialogue with the Sixth Committee and meeting the expectations of States are certainly the best way of doing this. Especially as the likelihood of a convention being signed and ratified is greater if it meets the expectations of States.

Now, however, much of the Commission's work is no longer designed to be the basis for the adoption of a convention but settles, sometimes successfully, for the status of soft law. A good example are the Commission's articles on the responsibility of States for internationally wrongful acts. ${ }^{4}$ The question of the adoption of a convention on the topic is still being studied in the General Assembly. Yet the articles have been widely accepted in practice and are cited specifically by numerous international courts and tribunals, such as the International Court of Justice, and frequently by arbitral tribunals of the International Centre for Settlement of Investment Disputes. ${ }^{5}$ There is also interest in the guide to practice on reservations to treaties. ${ }^{6}$

4 ILC, 'Draft articles on responsibility of States for internationally wrongful acts' [2001] II(2) ILC Ybk 26.

5 See United Nations, Materials on the Responsibility of States for Internationally Wrongful Acts (United Nations Legislative Series 2012); and United Nations, 'Responsibility of States for internationally wrongful acts. Compilation of decisions of international courts, tribunals and other bodies' (2016) UN Doc A/71/80.

6 ILC, 'Guide to practice on reservations to treaties' [2011] II(3) ILC Ybk 23. 
However, this trend raises questions about the nature of the Commission's work and of international law. Is the Commission not at risk, in certain cases, of producing drafts of an academic nature, sometimes with an ideological or symbolic dimension? Is there not, in turn, a danger that States may lose interest in some outcomes of the Commission's work if they do not take into account the expectations, the wishes or the practices of States?

Ways of Improving the Relationship between the International Law Commission and the Member States of the United Nations

Based on these comments, there are several possible ways of improving the relationship between the International Law Commission and the Member States of the United Nations.

First, it would be desirable for the Commission to refocus on its central mission: general international law. It is unrealistic to expect the Commission to work effectively and with the necessary expertise on overly specialized technical topics.

Second, reforms of a practical nature could considerably improve the way the Commission functions and enhance its working relationship with Member States. For instance, it would be useful to limit to four or five the number of topics considered each year. This would enable the Commission to make more rapid progress on each one, or at least to study them in greater depth. Above all, it would permit a genuine dialogue with States: it is impossible to imagine that all States are able to digest in two months an annual report that in recent years has covered about a dozen subjects in very diverse areas.

Third, the Commission should be able to adopt a truly universal approach, by enhancing its ability to understand the practice and the precedents of the various regions of the world and by strictly observing the rules concerning its linguistic coverage. In this connection, use of the working languages can improve the quality of the written work of the Commission, particularly in its Drafting Committee.

Fourth, States must more clearly convey their expectations regarding the Commission and its work. States should propose topics for the attention of the Commission. The topics in the Commission's current programme of work were all included on the proposal of the Commission itself. It is noteworthy, however, that Poland recently proposed the inclusion of a new topic (Nonrecognition) in the Commission's work programme. In 2017, several topics were - exceptionally - proposed by States. It is to be hoped that this trend will continue. 
As mentioned, States exert a decisive influence on the productivity of the Commission through the election of its members. According to the Commission's statute, they must propose candidates "of recognized competence in international law". ${ }^{7}$ Consequently, States must ensure that all candidates are in a position to make an active and useful contribution to the Commission's work.

States must also assist the Commission in its work by means of the information which they can provide to it and the dialogue in which they must engage. This could, for example, mean collaboration with academia, as was the case recently when the Codification Division was preparing its memorandum on ways and means for making the evidence of customary law more readily available. ${ }^{8}$

In conclusion, it is to be hoped that dialogue between the Commission and States can once again become a strong and positive force. This undoubtedly requires an effort on the part of the Commission. It also requires an effort on the part of States. The debate on the Commission's report at the autumn session of the Sixth Committee in New York is the best place for dialogue with Member States, because of the presence of numerous legal advisers visiting from the capitals, while the Commission sessions in Geneva should be preserved to ensure that the work of the Commission can proceed optimally.

7 Statute of the ILC (n 1$)$ article $2(1)$.

8 UN Doc A/CN.4/710. 